\title{
The Effects of Edaravone on Experimental Brain Ischemia/Reperfusion Injury in Rats
}

\author{
Elif Acar Arslan 1, Erhan Arslan², Serap Özer Yaman33, Süleyman Caner Karahan³ \\ ${ }^{1}$ Department of Pediatric Neurology, Karadeniz Technical University Faculty of Medicine, Trabzon, Turkey \\ ${ }^{2}$ Department of Neurosurgery, Karadeniz Technical University Faculty of Medicine, Trabzon, Turkey \\ ${ }^{3}$ Department of Biochemistry, Karadeniz Technical University Faculty of Medicine, Trabzon, Turkey
}

\begin{abstract}
Introduction: Millions of people worldwide die or are disabled every year due to acute ischemic stroke. In this study, our aim was to demonstrate the neuroprotective effects of Edaravone in experimental cerebral ischemia/reperfusion injury in rats. Methods: Twenty-eight female Sprague Dawley rats were divided into four main groups. The ischemia group underwent bilateral carotid artery clipping and hypotension for $30 \mathrm{~min}$. The Edavarone group received intraperitoneal $30 \mathrm{mg} / \mathrm{kg} / \mathrm{day}$ Edavarone following 30-min bilateral carotid artery clipping+hypotension. Skin laceration only was applied to the control group, and anesthesia only was applied for $15 \mathrm{~min}$ to the anesthesia group. At the end of the $10^{\text {th }}$ day, all rats were sacrificed, and blood samples and brain tissues were collected for analysis.

Results: Ischemia group malondialdehyde (MDA) values were significantly higher than those of the control and Edaravone groups. Edaravone group tissue MDA values $(258 \pm 13.8 \mathrm{nmol} / \mathrm{g})$ were significantly lower than those of the ischemia group $(368 \pm 36.6 \mathrm{nmol} / \mathrm{g})(\mathrm{p}<0.05)$. Edaravone group tissue total oxidant status (TOS) was significantly lower than in the anesthesia and ischemia groups $\left(96.9 \pm 13.4 \mathrm{mmol} \mathrm{H}_{2} \mathrm{O}_{2} \mathrm{Eq} / \mathrm{L}(\mathrm{g})\right)$. A statistically significant difference was observed between the groups serum TOS values $(p<0.05)$.

Discussion and Conclusion: This study shows that Edaravone reduced or prevented ischemic damage in rat brain tissue by causing significant changes in oxidant and antioxidant parameters.

Keywords: Cerebral ischemia/reperfusion injury; edaravone; neuroprotective.
\end{abstract}

$S^{\text {titisin }}$ troke is the fourth leading cause of death and disability in Japan ${ }^{[1]}$. According to data from the World Health Organization (WHO), approximately 15 million people have a stroke each year all around the world ${ }^{[2]}$. Many clinical and preclinical studies are ongoing to prevent neuron damage. Unfortunately, only several studies have shown clinical benefit ${ }^{[3]}$. Acute ischemic stroke causes excessive entry of $\mathrm{Ca} 2+$ ions into the cell and the formation of reactive oxygen species (ROS), resulting in the death of neuron cells due to mitochondrial dysfunction ${ }^{[4]}$.
Edaravone has been shown to capture and reduce excess ROS and thus prevent brain damage after ischemic stroke ${ }^{[5]}$. In 2001, edaravone was approved in Japan to improve neurological symptoms due to impaired daily living activities after an acute ischemic stroke ${ }^{[6,7]}$. The clinical use of edaravone in patients with acute ischemic stroke has not yet been approved in Turkey. In this study, we aimed to investigate the neuroprotective effects of edaravone on ischemia by creating experimental focal brain ischemia in rats (especially in the hippocampus region of the brain).

Correspondence (İletişim): Erhan Arslan, M.D. Karadeniz Teknik Universitesi Tip Fakultesi, Beyin Cerrahisi Anabilim Dali, 61080 , Trabzon, Turkey Phone (Telefon): +90 4623771028 E-mail (E-posta): arserhan@gmail.com 


\section{Materials and Methods}

\section{Experimental Animals}

Twenty-eight female Sprague- Dawley rats weighing 220$280 \mathrm{~g}$ were used in this study. General health of the rats was monitored under standard conditions. Animals were kept in separate cages without any pre-study limitation on access to water or feed restriction. Each rat was marked according to the assigned group. Ethics Committee approval was obtained for the animal experiments (No: 53488718204). Rats were divided into four main groups as follows:

Group I (Edoravane): In these seven rats, $30 \mathrm{mg} / \mathrm{kg}$ Edoravane was administered intraperitoneally daily following a 30-minute bilateral carotid artery clipping + hypotension.

Group II (Control): These seven rats were exposed to skin laceration only.

Group III (pure control group = anesthesia group): Seven rats were anesthetized for only 15 minutes.

Group IV (ischemia): These seven rats were exposed to bilateral carotid artery clipping and hypotension for 30 minutes.

At the end of the tenth day, all animals were sacrificed, and blood samples and brain tissues were collected for analysis.

\section{Anesthesia and Surgical Procedure}

The rats were given only water for 24 hours before surgery. Anesthesia was provided by intraperitoneal administration of $30 \mathrm{mg} / \mathrm{kg}$ ketamine hydrochloride (Ketalar, Pfizer, Istanbul) with $10 \mathrm{mg} / \mathrm{kg}$ xylazine hydrochloride (Rompun ${ }^{\circledR}$; Bayer Healthcare). Rats were numbered with ear tags. Their anterior cervical areas were shaved and cleansed with $10 \%$ polyvinylpyrrolidone-iodine. A midline skin incision was made and a retractor was inserted into the surgical field. Bilateral paratracheal regions were dissected by blunt dissection to expose a. carotid communis. After N. vagus was dissected bilaterally from a. carotid communis, aneurysm clips were applied to each A. carotid communis (Fig. 1) with a $50 \mathrm{~g}$ closure force (Yasargil FE 693, Aesculap, Germany). Yaşargil aneurysm clips were bilaterally applied to a. carotid communis for $30 \mathrm{~min}$. At the end of this period, approximately $3 \mathrm{cc}(10 \mathrm{ml} / \mathrm{kg})$ of intracardiac blood was withdrawn and hypotension was applied. Arterial flow was checked when the clips were removed after 30 minutes and the cut layers were properly sutured. All animals except the control group and anesthesia group underwent these surgical procedures. After anesthesia, the midline skin incision was performed and sutured in the control group.

The rats in the anesthesia group were anesthetized without

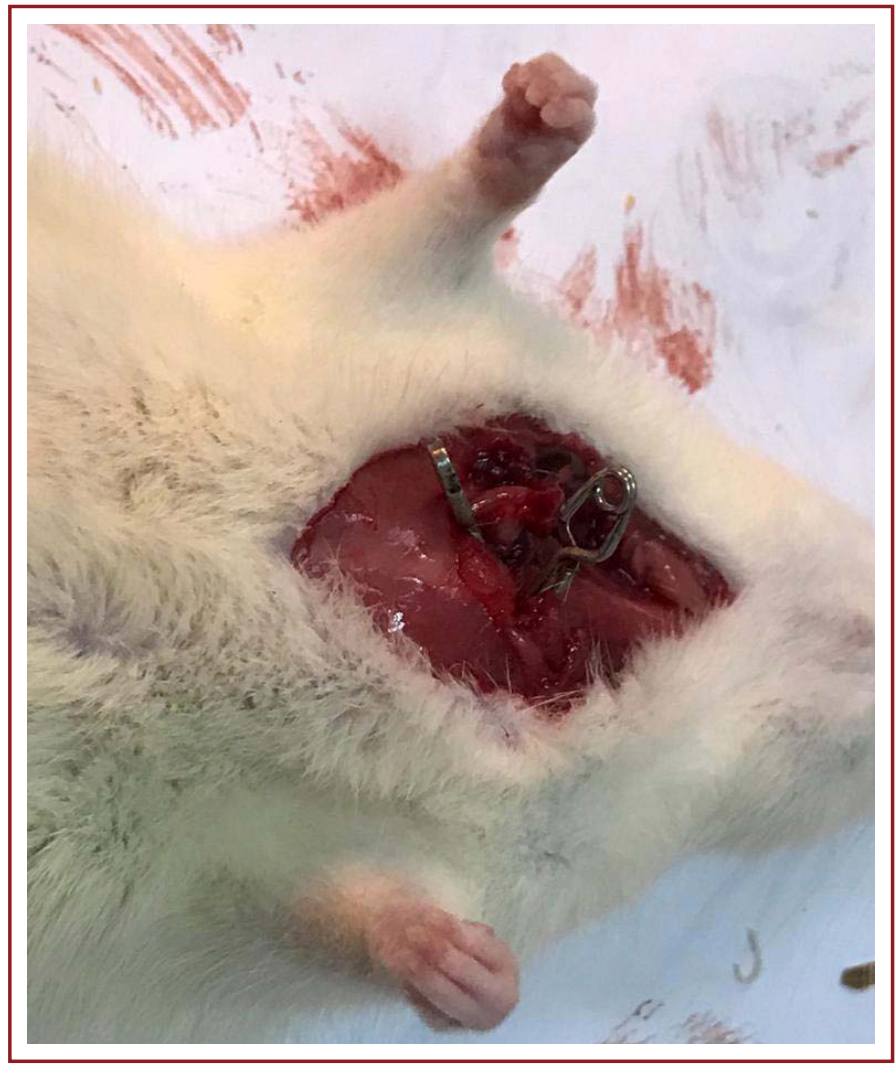

Figure 1. Closure of bilateral A. carotid communis of rats using Yaşargil aneurysm clips.

any surgical intervention. Neurological examinations were performed in four groups at the end of days 1, 4, 7 and 10 . At the end of the tenth day, the animals were sacrificed; blood samples and brain tissues were taken.

\section{Scarification of Rats and Sample Preparation}

Rats were sacrificed with a guillotine after taking approximately $4 \mathrm{cc}$ intracardiac blood. The hippocampus was extracted from the brain for biochemical analysis and stored at $-76^{\circ} \mathrm{C}$ in the freezer for homogenization. An Ultra-Turrax homogenizer (model T25, Janke and Kunkel, Germany) at $9500 \mathrm{rpm}$ was used $\left(4 \times 10\right.$ seconds at $\left.4{ }^{\circ} \mathrm{C}\right)$. Results were analyzed according to the codes given in the biochemistry laboratory.

\section{Determination of Malondialdehyde (MDA) Levels in Tissue and Serum Samples}

Lipid peroxidation levels in tissue and serum samples were determined by measuring MDA levels using the method previously described by Mihara and Uchiyama ${ }^{[8]}$. Tissues were weighed and homogenized in a $1.15 \% \mathrm{KCl}$ solution containing $0.5 \mathrm{~mL} / \mathrm{L}$ triton-X100 using a homogenizer (UItra Turrax T25, Rose Scientific Ltd., Edmonton, Canada). The 
homogenate was then centrifuged at $1800 \mathrm{~g}$ for $10 \mathrm{~min}$ utes. MDA levels in the obtained supernatant were measured spectrophotometrically. Tissue MDA levels were expressed as $\mathrm{nmol} / \mathrm{g}$ wet tissue.

MDA levels in rat serum samples were determined using the Thiobarbituric Acid Reagent (TBARS) method developed by Yagi ${ }^{[9]}$. The red color resulting from the reaction between lipid peroxidation product (MDA) and TBA was measured spectrophotometrically. MDA levels in serum samples were expressed as $\mathrm{nmol} / \mathrm{mL}$.

\section{Determination of Total Antioxidant Status (TAS) and Total Oxidant Status (TOS) in Tissue and Serum Samples}

Commercial colorimetric kits were used to determine TAS, and TOS values in serum and tissue samples (Rel Assay Diagnostics, Gaziantep, Turkey). Serum TOS and TAS values were determined using the new automatic and calorimetric method developed by Erel et al. ${ }^{[10,11]}$. TOS results were expressed as $\mu \mathrm{moL} \mathrm{H}_{2} \mathrm{O}_{2}$ equivalent/L for serum samples and $\mu \mathrm{moL} \mathrm{H}_{2} \mathrm{O}_{2}$ equivalent/g wet tissue for tissue samples. TAS results were expressed as $\mathrm{mmoL}$ Trolox Eq/L in serum samples and $\mathrm{mmoL}$ Trolox Eq/g wet tissue in tissue samples. Oxidative status index (OSI) was calculated and expressed as TOS: TAS ratio.

The TAS unit of MmoL Trolox equivalent/L was converted to $\mu \mathrm{moL}$ trolox equivalent/ $L$ and the OSI was calculated using the following formula:

$\mathrm{OSI}=\left[\left(\mathrm{TOS}, \mathrm{momol} \mathrm{H}_{2} \mathrm{O}_{2} \mathrm{Eq} / \mathrm{L}\right) /(\mathrm{TAS}\right.$, momol Trolox Eq/L)x10].

\section{Statistical Evaluation}

Statistical analysis was performed using SPSS 23.0 statistical package program. The suitability of the data for nor- mal distribution was evaluated using the Shapiro-Wilk test. Since the data of the parameters fit the normal distribution, One-Way ANOVA test was used for the general comparison of the groups. Comparisons between groups were made using the Tukey test. Statistical significance level was accepted as $\mathrm{p}<0.05$.

\section{Results}

Our study results are shown in Tables 1 and 2 .

Tissue MDA ( $\mathrm{nmol} / \mathrm{g}$ ) values were significantly different between the groups $(p<0.05)$. Tissue MDA levels were significantly lower (170 \pm 17.9$)$. In the control group compared to edaravone, anesthesia and ischemia groups, Tissue MDA levels in the ischemia group were significantly higher than the control and edaravone groups. The tissue MDA values of Edaravone group (258 \pm 13.8$)$ were significantly lower than the ischemia group $(368 \pm 36.6)(p<0.05)$.

There was no significant difference between the groups in terms of tissue TAS mmoL Trolox Eq/L ( $g$ ) values ( $p>0.05$ ).

Tissue TOS ( $\mu \mathrm{moL} \mathrm{H}_{2} \mathrm{O}_{2} \mathrm{Eq} / \mathrm{L}(\mathrm{g})$ ) values were significantly different between the groups $(p<0.05)$. Tissue TOS values of the control group were significantly lower relative to edaravone, anesthesia and ischemia groups (57.3 \pm 5.65$)$. Tissue TOS values of the ischemia group were significantly higher relative to the control and edaravone groups $(134 \pm 35.0)(p<0.05)$. Tissue TOS values of Edaravone group were significantly lower relative to anesthesia and ischemia groups $(96.9 \pm 13.4)$.

Significant differences were also observed between the groups in terms of tissue OSI values $(p<0.05)$. Tissue OSI values of the control group were significantly lower relative to edaravone, anesthesia and ischemia groups $(0.757 \pm 0.045)$. Tissue OSI values of the ischemia group were significantly

Table 1. Levels of parametres measured in serum, and tissue samples

\begin{tabular}{|c|c|c|c|c|c|}
\hline Parametre & $\begin{array}{c}\text { Edaravone } \\
\quad(n=7)\end{array}$ & $\begin{array}{c}\text { Control } \\
(n=7)\end{array}$ & $\begin{array}{c}\text { Anesthesia } \\
(\mathbf{n}=7)\end{array}$ & $\begin{array}{l}\text { Ischemia } \\
\quad(n=7)\end{array}$ & $\mathbf{p}^{*^{\wedge}}$ \\
\hline Tissue MDA ( $\mathrm{nmol} / \mathrm{g}$ wet tissue ) & $258 \pm 13.8^{a}$ & $170 \pm 17.9$ & $291 \pm 46.2^{\mathrm{a}}$ & $368 \pm 36.6^{\text {a.e }}$ & 0.0001 \\
\hline Tissue TAS mmol Troloks Eq/g wet tissue & $7.50 \pm 0.804$ & $6.98 \pm 0.796$ & $6.80 \pm 0.954$ & $7.09 \pm 0.946$ & 0.198 \\
\hline Tissue TOS $\mu m o l ~ H 2 O 2$ Ek/g wet tissue & $96.9 \pm 13.4^{\mathrm{a}}$ & $57.3 \pm 5.65$ & $123 \pm 13.4^{\mathrm{a}}$ & $134 \pm 35.0^{\text {a.e }}$ & 0.0001 \\
\hline Tissue OSI & $1.31 \pm 0.287^{a}$ & $0.757 \pm 0.045$ & $1.82 \pm 0.379^{a}$ & $1.92 \pm 0.436^{\text {a.e }}$ & 0.0001 \\
\hline Serum TAS mmol Troloks Eq/L & $2.02 \pm 0.292$ & $2.27 \pm 0.191$ & $2.24 \pm 0.152$ & $2.05 \pm 0.146$ & 0.133 \\
\hline Serum TOS $\mu \mathrm{mol} \mathrm{H} 2 \mathrm{O} 2 \mathrm{Eq} / \mathrm{L}$ & $10.3 \pm 1.90$ & $10.4 \pm 2.74$ & $22.6 \pm 12.9^{\text {a.e }}$ & $19.6 \pm 7.17$ & 0.006 \\
\hline Serum OSI & $0.520 \pm 0.113$ & $0.453 \pm 0.102$ & $1.01 \pm 0.568^{\text {a.e }}$ & $0.925 \pm 0.415$ & 0.006 \\
\hline IMA (ABSU) & $0.695 \pm 0.065$ & $0.632 \pm 0.089$ & $0.594 \pm 0.049$ & $0.704 \pm 0.092$ & 0.134 \\
\hline
\end{tabular}

*p values were determined using One-way ANOVA test. Intragroup post -hoc assessments were performed using "Tukey" test. Intergroup post-hoc analyses were performed using "Tukey" and "Tamhane's T2" tests. When a (control group) was compared with e (edavarone) group statistically significant differences were found $(p<0.05)$. 
Table 2. Intergroup comparisons of serum, and tissue parametres

\begin{tabular}{|c|c|c|c|}
\hline \multirow{3}{*}{$\begin{array}{l}\text { Parametres } \\
\text { Tissue MDA } \\
\text { (nmol/ wet tissue) }\end{array}$} & \multicolumn{2}{|c|}{$\begin{array}{c}\text { Comparator } \\
\text { groups }\end{array}$} & \multirow{2}{*}{$\begin{array}{c}{ }^{*} \mathbf{p} \\
0.0001\end{array}$} \\
\hline & Control & Anesthesia & \\
\hline & Control & Ischemia & 0.0001 \\
\hline & Anesthesia & Ischemia & 0.022 \\
\hline & Control & Edaravone & 0.006 \\
\hline & Ischemia & Edaravone & 0.0001 \\
\hline Tissue TOS $\mathrm{mmol}$ & Control & Anesthesia & 0.0001 \\
\hline \multirow[t]{3}{*}{$\mathrm{H}_{2} \mathrm{O}_{2} \mathrm{Eq} / \mathrm{L}$ (g wet tissue) } & Control & Ischemia & 0.0001 \\
\hline & Control & Edaravone & 0.002 \\
\hline & Ischemia & Edaravone & 0.005 \\
\hline \multirow[t]{4}{*}{ Tissue OSI } & Control & Anesthesia & 0.0001 \\
\hline & Control & Ischemia & 0.0001 \\
\hline & Control & Edaravone & 0.025 \\
\hline & Ischemia & Edaravone & 0.009 \\
\hline Serum TOS $\mathrm{mmol}$ & Control & Anesthesia & 0.020 \\
\hline $\mathrm{H}_{2} \mathrm{O}_{2} \mathrm{Eq} / \mathrm{L}$ & Edaravone & Anesthesia & 0.013 \\
\hline \multirow[t]{2}{*}{ Serum OSI } & Control & Anesthesia & 0.027 \\
\hline & Edaravone & Anesthesia & 0.048 \\
\hline
\end{tabular}

Potansiyel-hoc analyses between groups were performed using "Tukey's Tamhane's T2" tests P values of $<0.05$ were accepted as statistically significant.

higher relative to the control and edaravone groups (1.92 \pm 0.436$)$.

There was no statistically significant difference in serum MDA ( $\mathrm{nmol} / \mathrm{mL}$ ) between the groups ( $\mathrm{p}>0.05)$. Serum MDA levels in the ischemia group were slightly higher relative to the other groups, but this difference was not significant. There was no statistically significant difference between the groups in terms of serum TAS mmoL Trolox Eq/L values $(p>0.05)$. Serum TOS $\mu \mathrm{moL} \mathrm{H}_{2} \mathrm{O}_{2} \mathrm{Eq} / \mathrm{L}$ values were significantly different between the groups $(p<0.05)$. Serum TOS $\mu \mathrm{mol} \mathrm{H}_{2} \mathrm{O}_{2} \mathrm{Eq} / \mathrm{L}$ values in the anesthesia group were significantly higher relative to the edaravone and control groups (22.6 \pm 12.9$)$.

Significant differences in serum OSI values were shown between the groups $(p<0.05)$. Serum OSI values in the anesthesia group were significantly higher relative to edaravone and control group $(1.01 \pm 0.568)$. There was no significant difference in IMA (ABSU) between the groups ( $p>0.05$ ). The IMA (ABSU) values of the ischemia group were slightly higher than those of the other groups without any significant difference $(p=0.134)$.

\section{Discussion}

Edaravone (3-methyl-1-phenyl-2-pyrazoline-5-one) is a powerful free radical scavenger that exhibits antioxidant effects by inhibiting hydroxyl radical-dependent and radical-independent lipid peroxidation ${ }^{[7,12]}$. Edaravone has been shown to have beneficial effects on oxidative stress markers, including glutathione, superoxide dismutase, malondialdehyde and glutathione peroxidase ${ }^{[13]}$. Its neuroprotective effect against oxidative stress in patients with cerebral infarction and acute ischemic stroke has been demonstrated ${ }^{[14]}$. In vivo and in vitro studies have found that edaravone has a neuroprotective effect in animal models of amyotrophic lateral sclerosis and Parkinson's disease ${ }^{[15,16]}$.

Cerebral tissue damage during stroke occurs as a result of various interactions such as acidotoxicity, excitotoxicity, ionic imbalance, oxidative and nitrate stress, infarction and apoptosis [17]. Many agents are used, including glutamate receptor antagonists, calcium channel blockers, free radical scavengers, and anti-inflammatory, anti-emetic and antiaggregating agents to prevent and treat ischemia-reperfusion injury ${ }^{[18]}$.

Infiltration of calcium and outer ions into cells, cellular edema, activation of the intracellular kinase and protease enzymes, overproduction of reactive nitrosative and oxidative products, cell membrane damage and organelle failure contribute to the early appearance of excitotoxicity in mutually linked pathways. This series leads to an inflammatory response that begins and develops in the first hours following ischemia.

These sequelae result in an increase in intracellular adhesion molecule-1 (ICAM-1) and adhesion molecules in the endothelium, and an increase in the associated $\mathrm{P}$-selectin, chemokines, macrophages and neutrophils into the tissue. Increased calcium in the cytoplasm inhibits the electron transport chain at the mitochondrial level and increases the synthesis of nitric oxide that promotes the formation of superoxide anions and peroxynitrite formation [19, 20]. Other pathophysiological changes include endothelin release, leukocyte and platelet activation, delayed clotting, and endothelial dysfunction [21]. Ischemia-induced glutamate release increases, astrocyte cell function is impaired and astrocyte cell-mediated glutamate uptake is compromised ${ }^{[22-25]}$. Irreversible neuronal damage increases as a result of various mechanisms, such as lipid peroxidation of calcium, activation of proteolytic enzymes, free radical production, and activation of genes ${ }^{[22]}$. Lipid peroxidation is the most important cause of reperfusion injury. Increased free radicals initiate lipid peroxidation in neuronal cells, plasma, organelle membranes, vascular endothelial cell membrane and myelin ${ }^{[26]}$. 
In this study, we demonstrated that edaravone has a protective effect against ischemia-reperfusion injury by affecting serum and cerebral tissue levels of MDA, a product of lipid peroxidation. In this study, high levels of MDA (an important component of oxidation in hippocampal ischemic tissue) TOS, OSI have been shown. In contrast, tissue MDA, TOS, and OSI values were significantly lower in edaravonetreated rats compared to ischemic tissue. This finding is important for the demonstration of the antioxidant properties of edaravone at tissue level.

In this study, oxidant and antioxidant parameters of TAS, TOS and OSI in cerebral tissue and serum were also examined and the neuroprotective effects of edaravone was confirmed. We used the bilateral carotid clipping + hypotension model to demonstrate the neuroprotective effect of edaravone in ischemia-reperfusion injuries. MDA and TOS increased significantly in cerebral tissue samples taken from rats in ischemia groups with oxidative stress compared to control and edaravone groups. The absence of a significant increase in tissue TAS values between the groups is probably due to insufficiency of compensatory antioxidant mechanisms developed against oxidative stress in the cerebral tissue during the study period.

\section{Conclusion}

In this study, edaravone has been shown to reduce or prevent ischemic damage in brain tissue by making significant changes in oxidant and antioxidant parameters and its neuroprotective effect has been ALSO confirmed. This study may promote the use of edaravone in patients with cerebral ischemia, but further studies should be conducted on this subject.

Ethics Committee Approval: The study was approved by the Karadeniz Technical University Experimental Animal Ethics Commitee (approval number: 53488718-204, date: April 6, 2017), Trabzon, Turkey.

Peer-review: Externally peer-reviewed.

Authorship Contributions: Concept: E.A.A., E.A.; Design: E.A.; Data Collection or Processing: E.A., S.Ö.Y.; Analysis or Interpretation: E.A.A., E.A., S.Ö.Y., S.C.K.; Literature Search: E.A.A., E.A. ; Writing: E.A.A., E.A.

Conflict of Interest: None declared.

Financial Disclosure: The authors declared that this study received no financial support.

\section{References}

1. Japan Preventive Association of Life-Style Related Disease. [cited 13 Oct 2016]. Available at: http://www.seikat susyukan- byo.com/statistics/2016/009225.php. Accessed 2017.

2. The internet stroke center-stroke statistics. [cited May 2016]. Available at: http://www.strokecenter.org/patients/aboutstroke/stroke-statistics/.

3. Matsumoto S, Murozono M, Kanazawa M, Nara T, Ozawa T, Watanabe $\mathrm{Y}$. Edaravone and cyclosporine $\mathrm{A}$ as neuroprotective agents for acute ischemic stroke. Acute Med Surg 2018;17;5:213-21.

4. Siesjö BK, Elmér E, Janelidze S, Keep M, Kristián T, Ouyang YB, et al. Role and mechanisms of secondary mitochondrial failure. Acta Neurochir Suppl 1999;73:7-13.

5. Watanabe T, Tanaka M, Watanabe K, Takamatsu Y, Tobe A. Research and development of the free radical scavenger edaravone as a neuroprotectant. [Article in Japanese] Yakugaku Zasshi 2004;124:99-111.

6. Takei K, Watanabe K, Yuki S, Akimoto M, Sakata T, Palumbo J. Edaravone and its clinical development for amyotrophic lateral sclerosis. Amyotroph Lateral Scler Frontotemporal Degener. 2017;18:5-10.

7. The Edaravone Acute Brain Infarction Study Group. Effect of a novel free radical scavenger, edaravone (MCl-186), on acute brain infarction. Randomized, placebo-controlled, doubleblind study at multicenters. Cerebrovasc Dis 2003;15:222-9.

8. Mihara M, Uchiyama M. Determination of malonaldehyde precursor in tissues by thiobarbituric acid test. Anal Biochem 1978;86:271-8.

9. Yagi K. Assay for blood plasma or serum. Methods Enzymol. 1984;105:328-31.

10. Erel O. A new automated colorimetric method for measuring total oxidant status. Clin Biochem 2005;38:1103-11.

11. Erel O. A novel automated method to measure total antioxidant response against potent free radical reactions. Clin Biochem. 2004;37:112-9.

12. Edaravone Acute Infarction Study Group; Effect of a novel free radical scavenger, edaravone (MCl-186), on acute brain infarction. Randomized, placebo-controlled, double-blind study at multicenters. Cerebrovasc Dis. 2003;15:222-9.

13. Zhou S, Yu G, Chi L, Zhu J, Zhang W, Zhang Y, et al. Neuroprotective effects of edaravone on cognitive deficit, oxidative stress and tau hyperphosphorylation induced by intracerebroventricular streptozotocin in rats. Neurotoxicology 2013;38:136-45.

14. Alhaider IA. Effects of edaravone on scopolamine induced-dementia in experimental rats. Int J Pharmacol 2013;9:271-6.

15. Yoshida H, Yanai H, Namiki Y, Fukatsu-Sasaki K, Furutani N, Tada N. Neuroprotective effects of edaravone: a novel free radical scavenger in cerebrovascular injury. CNS Drug Rev 2006;12:9-20.

16. Kikuchi K, Takeshige N, Miura N, Morimoto Y, Ito T, Tancharoen $S$, et al. Beyond free radical scavenging: Beneficial effects of edaravone (Radicut) in various diseases. Exp Ther Med 2012;3:3-8.

17. Arslan FC, Tiryaki A, Yıldırım M, Özkorumak E, Alver A, Altun IK, et al. The effects of edaravone in ketamine-induced model of 
mania in rats. Acta Neurobiol Exp (Wars) 2016;76:192-8.

18. Doyle KP, Simon RP, Stenzel-Poore MP. Mechanisms of ischemic brain damage. Neuropharmacology 2008;55:310-8.

19. Love S. Apoptosis and brain ischaemia. Prog Neuropsychopharmacol Biol Psychiatry 2003;27:267-82.

20. Bull R, Finkelstein JP, Gálvez J, Sánchez G, Donoso P, Behrens $\mathrm{Ml}$, et al. Ischemia enhances activation by $\mathrm{Ca} 2+$ and redox modification of ryanodine receptor channels from rat brain cortex. J Neurosci 2008;28:9463-72.

21. Moncada S, Erusalimsky JD. Does nitric oxide modulate mitochondrial energy generation and apoptosis? Nat Rev Mol Cell Biol 2002;3:214-20.

22. Xu XH, Zhang SM, Yan WM, Li XR, Zhang HY, Zheng XX. Development of cerebral infarction, apoptotic cell death and expression of X-chromosome-linked inhibitor of apoptosis protein following focal cerebral ischemia in rats. Life Sci 2006;78:704-12.
23. Gupta YK, Briyal S. Animal models of cerebral ischemia for evaluation of drugs. Indian J Physiol Pharmacol 2004;48:379-94.

24. Budd SL. Mechanisms of neuronal damage in brain hypoxia/ ischemia: focus on the role of mitochondrial calcium accumulation. Pharmacol Ther 1998;80:203-29.

25. Mehta SL, Manhas N, Raghubir R. Molecular targets in cerebral ischemia for developing novel therapeutics. Brain Res Rev 2007;54:34-66.

26. Mori T, Tateishi N, Kagamiishi Y, Shimoda T, Satoh S, Ono S, et al. Attenuation of a delayed increase in the extracellular glutamate level in the peri-infarct area following focal cerebral ischemia by a novel agent ONO-2506. Neurochem Int 2004;45:381-7.

27. Zhao Z, Lu C, Li T, Wang W, Ye W, Zeng R, et al. The protective effect of melatonin on brain ischemia and reperfusion in rats and humans: In vivo assessment and a randomized controlled trial. J Pineal Res 2018;65:e12521. 